\title{
Indigenous Mental Health: IMAgining a Future Where ACtion Follows Obligations ANd Promises
}

\author{
COnStAnCE MaCIntosh ${ }^{*}$
}

\begin{abstract}
This article considers what it would mean if Canada fulfilled select existing commitments and obligations concerning the mental health needs of Indigenous peoples, as identified through current programs and recent jurisprudence: that is, where would we be if Canada carried through on existing commitments? After identifying the role of law in perpetuating poor mental well-being, it assesses programs for First Nations and Inuit peoples and determines they are unlikely to be effective without operational changes and responsive funding. The article then turns to the situation of Metis and non-status First Nations and the implications of Daniels v. Canada for changing the status quo - both by requiring appropriate mental health supports, and by dismantling the racist legal logic that has long undermined the mental well-being of non-status First Nations and Metis persons, by positioning them as not counting as true Indigenous peoples. The article concludes that merely fulfilling current state obligations could bring considerable short-term gains, and some long-term gains, for the mental well-being of Indigenous peoples in Canada.
\end{abstract}

\section{TABLE OF CONTENTS}

I. INTRODUCTION . . . . . . . . . . . . . . . . . . . . . . . . . . . . . . . . 589

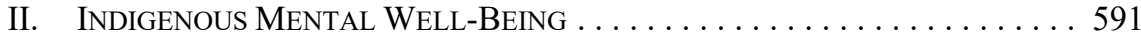

III. COMMITTING TO COMMITMENTS:

Making Existing Policy-Based Programs Real . . . . . . . . . . . . 593

A. The Non-Insured Health Benefits Program:

Mental HeAlth Benefits . . . . . . . . . . . . . . . . . . . . . 595

B. Community HeAlth Initiatives . . . . . . . . . . . . . . . . . . 598

IV. IMPLEMENTING THE PROMISE OF DANIELS $V$.

CANADA (INDIAN AFFAIRS AND NORTHERN DEVELOPMENT . . . . . . . . . 601

A. HistORIC BACKDROP . . . . . . . . . . . . . . . . . . . . . . 602

B. LIKELY DIRECT IMPACTS OF DANIELS

FOR MENTAL SUPPORTS AND RESOURCES . . . . . . . . . . . . . . . . 604

C. INDIRECT CONSEQUENCES: DANIELS IN THE

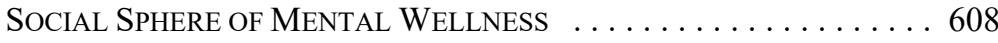

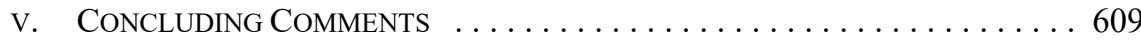

\section{INTRODUCTION}

In 1995, the Royal Commission on Aboriginal Peoples released a special report on suicide among Aboriginal peoples in Canada. Suicide was described as being one of the most urgent problems facing Aboriginal communities. ${ }^{1}$ Subsequent reports, studies, and events affirm the continuing prevalence of mental health concerns, including suicide, for Inuit, Metis, and First Nations persons residing both on and off reserve. For example, in 2007, the Inuit Tapitiit

Associate Professor, Schulich School of Law, Dalhousie University, Former Director of Dalhousie's Health Law Institute. My thanks to Colleen Flood and the national health law community for continuing to push me to work in this area, and to Kate Scallion for her invaluable research assistance.

$1 \quad$ Nancy Miller Chenier, Suicide Among Aboriginal People: Royal Commission Report, Canada Library of Parliament Mini-Review MR-131E (Ottawa: Library of Parliament Research Branch, 1995) at 1. 
Kanatami identified mental wellness as the "number one Inuit health priority." A 2012 national survey confirmed that the off reserve Aboriginal population, including non-status Aboriginal people and Metis people, had heightened rates of suicidal thoughts compared to the non-Aboriginal population, as well as heightened rates of other mental health issues, and completed suicides. ${ }^{3}$ In 2016, Canadian newspapers broke the story that over 101 individuals living in the Indigenous community of Attawapiskat - whose population only numbers around 2,000 — had attempted suicide in the eight months leading up to April 2016, including many children. ${ }^{4}$ Three years prior, the small First Nations community of Neskantaga declared a state of emergency, seeking assistance after two individuals completed suicide in a week, the culmination of more than 20 suicide attempts in the previous year. ${ }^{5}$ In the two decades since the Royal Commission report was released, progress in addressing not just suicide within Aboriginal communities, but other issues associated with mental health and well-being has not been sufficient.

In this brief article, I consider the implications if we are attentive to meaningfully fulfilling select current state commitments and obligations, as identified through existing programs or suggested by recent case law. I do not attempt a comprehensive review. My goal is to draw attention to the fact that merely acting on current obligations could permit considerable short-term gains for the mental well-being of Indigenous peoples in Canada. As well as being a common sense suggestion, meaningful follow-through is certainly within the scope of the rights recognized under the United Nations Declaration on the Rights of Indigenous Peoples, ${ }^{6}$ which Canada recently committed to implementing. UNDRIP obliges states to "take the necessary steps" to enable Indigenous people to progressively achieve the "highest attainable standard of physical and mental health." Effective implementation of existing commitments and obligations is obviously one such "necessary step."

Below, I first discuss the issue of Indigenous mental well-being, generally, and then turn to my assessment. I have identified one topic of relevance for considering the future mental well-being of status First Nations and Inuit persons and communities, and a second topic for considering the future mental well-being of Metis and non-status First Nations persons and communities. $^{8}$

Alianait Inuit-Specific Mental Wellness Task Group, Alianait Inuit Mental Wellness: Action Plan (Ottawa: Inuit Tapiriit Kanatami, 2007) at 1.

3 Mohan B Kumar, Lifetime Suicidal Thoughts Among First Nations Living Off Reserve, Metis and Inuit Aged 26 to 59: Prevalence and Associated Characteristics (Ottawa: Statistics Canada, 2016) at 3.

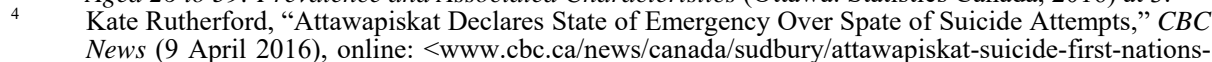
emergency-1.3528747>.

$5 \quad$ Norah Kielland \& Tonina Simeone, Current Issues in Mental Health in Canada: The Mental Health of First Nations and Inuit Communities, No 2014-02-E (Ottawa: Library of Parliament, 2014) at 1.

$6 \quad$ United Nations Declaration on the Rights of Indigenous Peoples, UNGAOR, 61st Sess, Sup No 49, UN Doc A/61/53 (2007) [UNDRIP].

Ibid, art 24(2).

Due to the requirement that the articles for this special edition be brief, I was unable to include a discussion of mental health supports within the corrections context. I have, however, described the gap between what Aboriginal inmates are able to access and what supports are supposed to be made available to them pursuant to law and policy elsewhere. See Constance MacIntosh, "Indigenous Peoples and Mental Health: The Role of Law and Policy" in Jennifer A Chandler \& Colleen M Flood, eds, Law and Mind: Mental Health Law and Policy in Canada (Toronto: LexisNexis Canada, 2016) 419 at 442-47 [MacIntosh, "Indigenous Peoples"]. 


\section{INDigenous Mental WeLl-Being}

Indigenous mental health is a complex field of inquiry. One of the reasons for this is that many Indigenous peoples experience and conceptualize mental well-being within a relational and holistic continuum, where mental, spiritual, physical, and economic well-being are all interwoven; these dimensions of health reach back to previous generations and forward to future ones. ${ }^{9}$ Indigenous peoples thus often experience unique determinants of health. ${ }^{10}$ Given this, it is little surprise that researchers find " $[\mathrm{m}]$ ental health service delivery models that are designed in keeping with the dominant biomedical views of mental health and illness, create barriers to access and often only inadequately recognize the health care needs of Aboriginal peoples." "11

Disjunctures are further illuminated through a growing literature that draws qualitative and quantitative links between the cumulative and interlocking impacts of unique social, economic, legal, political, and historic factors, and experiences of poor mental health and risk factors for poor mental health.

This aligns with the insights of intersectionality, that "different dimensions of social life cannot be separated into discrete and pure strands." 12 The Mental Health Commission of Canada points to how law has played a significant role in creating and perpetuating these conditions. The Commission describes legislation and policies directed at assimilation as having undermined Indigenous peoples' mental well-being for over 200 years. In particular, they trace the cultural disruptions caused by Indian Residential Schools and the historic child welfare system "to high rates of mental health problems, addictions and suicide among First Nations, Inuit, and Métis, linked with complex problems such as family violence and involvement in the criminal justice and child welfare systems."13 The intergenerational trauma associated with forced attendance at Indian Residential Schools is compounded further by related factors such as Indigenous communities being unlawfully dispossessed of land and their civil, political, legal, and social rights, which foster conditions that are implicated in engendering generations of life with poverty, food insecurity, overcrowded housing, inadequate access to health care and clean water, over-incarceration, generalized

For an in-depth discussion of the challenges associated with generalizing about Indigenous conceptions of mental well-being and commonly identified variations as between Indigenous peoples in Canada, see MacIntosh, "Indigenous Peoples," ibid; Constance MacIntosh, "The Role of Law in Ameliorating Global Inequalities in Indigenous Peoples' Health" (2013) 41:1 JL Med \& Ethics 74 at 76; Assembly of First Nations \& Health Canada, First Nations Mental Wellness Continuum Framework (Ottawa: Health Canada, 2015) at 4-5.

10 See e.g. Assembly of First Nations \& Health Canada, Honouring Our Strengths: A Renewed Framework to Address Substance Use Issues Among First Nations People in Canada (Ottawa: Ministry of Health, 2011) at 6 [Honouring Our Strengths].

11 V Smye, A Browne \& V Josewski, Supporting the Mental Wellness of First Nations, Inuit and Metis Peoples in Canada: Cultural Safety - A Research Discussion Paper (Health Canada, 15 June 2010) at 15, online: <www.mdsc.ca/documents/Publications/BUILDING\%20BRIDGES\%202_SCHEDULES $\% 20 A-E . p d f>$.

12 Avtar Brah \& Ann Phoenix, “Ain’t I a Woman? Revisiting Intersectionality” (2004) 5:3 J Intl Women’s Studies 75 at 76 .

13 Mental Health Commission of Canada, Changing Directions, Changing Lives: The Mental Health Strategy for Canada (Calgary: Mental Health Commission of Canada, 2012) at 96, online: <strategy. mentalhealthcommission.ca/pdf/strategy-images-en.pdf>. 
experiences of racism, ${ }^{14}$ and undermining individual and community identity and continuity. $^{15}$

Many of the connections between legal, historic, and societal factors and poor mental well-being were identified by communities and reported in the literature decades ago. For example, back in 1995, the Royal Commission on Aboriginal Peoples identified dispossession of land and lack of control over living conditions as factors that contribute to the heightened levels of suicide and suicidal ideation within the Aboriginal population. ${ }^{16}$ The report identified specific barriers to change such as Aboriginal peoples lacking power over programming that was supposed to serve them, unequal access to existing programs and resources, and jurisdictional confusion associated with there being multiple funding sources. More recent research has affirmed the continuing impact of such factors, and identified associated issues that adversely affect mental well-being. For example, the 2012 Aboriginal Peoples Survey linked Inuit peoples' heightened levels of mental distress with factors including food insecurity, failure to receive needed health care, overcrowded housing, and living with chronic physical conditions. ${ }^{17}$ Amy Bombay's empirical studies co-relate being a descendant of a residential school survivor and having higher rates of suicidal thoughts and suicide attempts than other Aboriginal people. In particular, the 2002-2003 Aboriginal Regional Health Survey found rates of suicidal thoughts for those Aboriginal people whose family members attended a residential school versus those whose did not were 37.2 percent versus 35.7 percent, respectively; rates of having attempted suicide were 20.4 percent versus 13.1 percent. $^{18}$ The more recent 2012 Aboriginal Peoples Survey's data on Inuit persons, whose overall suicide rates are between six and 11 times higher than the Canadian national average, ${ }^{19}$ similarly found associations between having oneself or a family member attend a residential school and heightened mental distress. ${ }^{20}$ Co-relations were also found between off-reserve First Nation and Metis persons having personal or familial residential school experiences and experiencing suicidal thoughts. ${ }^{21}$ Not surprisingly, when interviewed in 2016 about the rash of suicide attempts over the previous eight months, residents of Attawapiskat connected their situation to the lack of support services, overcrowded housing, drug abuse to self-medicate, physical and sexual abuse, and the continuing impact of residential schools on families. $^{22}$

The legacy of colonialism - in the form of intergenerational trauma and overarching issues about community control, identity, and self-determination - is prominent in the data described above; a lack of community resources and infrastructure is also present.

For a detailed discussion, see MacIntosh, "Indigenous Peoples," supra note 8 at 419

Constance MacIntosh, "Relational Theory and Indigenous Health: Insights for Law Reform and Policy Development" in Jocelyn Downie \& Jennifer J Llewellyn, eds, Being Relational: Reflections on Relational Theory and Health Law (Vancouver: UBC Press, 2012) 230 [MacIntosh, "Relational Theory"].

16 Nancy Miller Chenier, Suicide Among Aboriginal People: Royal Commission Report, Canada Library of Parliament MR-131E (Ottawa: Library of Parliament Research Branch, 1995) at 2.

Thomas Anderson, The Social Determinants of Higher Mental Distress Among Inuit (Ottawa: Statistics Canada, 2015) at $9,11,13$.

18 Amy Bombay, Kimberly Matheson \& Hymie Anisman, "The Intergenerational Effects of Indian Residential Schools: Implications for the Concept of Historical Trauma" (2014) 51:3 Transcultural Psychiatry 320 at 324 .

Anderson, supra note 17 at 7.

Ibid at 9 .

Kumar, supra note 3 at 9.

Rutherford, supra note 4. 
Very few Indigenous families, and likely no communities, can be presumed to be unscathed by suicide, addiction, and other mental wellness challenges. ${ }^{23}$ All are striving for transformation, for a future where well-being is a norm. While the discussion above points to multiple areas where law and policy reform is required, and a need to fundamentally change governance and economic norms, this article has a very modest scope and a shortterm focus. ${ }^{24}$ It is, essentially, a discussion about where we should already be if existing or nascent state-driven commitments and obligations are respected.

This article first identifies some of the existing programs that were designed to address aspects of the mental health needs described above. For reasons that become obvious, the focus here is the mental health situation of status First Nations persons and Inuit peoples. I consider the alignment between what the programs aim to do and how they are operationalized, and ask whether they are likely to give us a future that improves on the past. This is largely a discussion of policy. The article then shifts to the situation of other segments of the Indigenous population, in particular Metis and non-status First Nations persons. I approach the question of what their mental health situation may look like in the future by considering what it could mean if recent judicial declarations about federal obligations are respected. My inquiry in this brief article, then, is both retrospective and prospective, while always considering what the future of Indigenous mental health would look like if the Canadian state merely followed through on what it has already committed, or been found obliged, to do.

\section{Committing to Commitments: Making Existing Policy-Based Programs Real}

My first focus of inquiry is existing programming that is specifically intended to ameliorate Indigenous mental health. My conclusion is that, while the discussed programs target key issues, they are unlikely to achieve their potential to change the status quo unless operational changes are made, including ensuring adequate funding.

To understand how these programs are situated, it is important to recall that Indigenous peoples, as residents of provinces, have the right to access the same primary health care services that are available to all provincial residents. This follows from the Canada Health Act and its requirement that, in exchange for funding, provinces must provide insured health services to all its residents "on uniform terms and conditions." ${ }^{25}$ These provincial schemes are, for the most part, designed to serve the general population of the provinces. The gap between the health of Indigenous and non-Indigenous people in Canada has been described in national and provincial reports as "deplorable," "a national disgrace," and "simply

23 But see Michael J Chandler \& Christopher Lalonde, "Cultural Continuity as a Hedge Against Suicide in Canada's First Nations" (1998) 35:2 Transcultural Psychiatry 191 for a discussion of some First Nations reserve communities in British Columbia where youth suicide is not present.

24 For a discussion of a number of these issues, including how current child welfare regimes and the corrections system are implicated in Indigenous mental health, see MacIntosh, "Indigenous Peoples," supra note 8 at 419 .

25 Canada Health Act, RSC 1985, c C-6, ss 2, 10. The Canada Health Act defines insured persons as all residents of a province, with the exception of persons being held as inmates in federal penitentiaries, members of the Canadian Armed Forces, and those who have not yet completed a minimum residential requirement, which can be no longer than three months (ibid, s 2). It also excludes visitors and tourists. 
unacceptable." 26 With some very important exceptions, ${ }^{27}$ provincial schemes do not systematically include extraordinary or supplementary programming that has been customized to either address Indigenous health in general, or specifically address Indigenous mental wellness needs, and justify looking to the federal government to fill these needs on jurisdictional grounds.

The federal government has not been entirely unresponsive to the health gap. While it could use its spending power to indirectly shape or support provincial policy on this matter, as it has otherwise via the Canada Health Act $^{28}$ it has instead designed a number of tailored initiatives that it directly delivers, which include some mental health interventions. The federal government claims such direct interventions have a legal basis through section 91(24) of the Constitution Act, 1867, which makes "Indians, and Lands reserved for the Indians" a federal head of power. ${ }^{29}$ Indigenous peoples and many scholars point to section $91(24)$ as a codification of pre-existing obligations, and alternatively source federal health care obligations to Indigenous peoples in treaties, fiduciary relationships, and other historic instruments and promises. ${ }^{30}$

For the most part, these federal initiatives only serve the select portions of the Indigenous population for which the federal government has acknowledged jurisdictional responsibility. In particular, the federal government has long interpreted section 91(24) of the Constitution Act as resulting in it having jurisdiction over Inuit ${ }^{31}$ and status First Nations persons. ${ }^{32}$ That is, the federal government has made its jurisdictional reach contingent on definitional criteria for status, which the federal government itself created and codified in the Indian Act. The federal government has largely disavowed jurisdictional responsibility for the well-being of First Nations persons who did not qualify for status under the Indian Act, and for Metis

26 See Constance MacIntosh, "Indigenous Peoples and Health Law and Policy: Responsibilities and Obligations" in Jocelyn Downie, Timothy Caulfield \& Colleen M Flood, eds, Canadian Health Law and Policy, 4th ed (Toronto: LexisNexis, 2011) 575 at 575 [MacIntosh, "Responsibilities and Obligations"]. One important exception is found in Ontario, which has an Aboriginal Healing and Wellness Strategy. This Strategy has included creating 10 Aboriginal Health Access Centres, which provide both primary and community mental health care. In 2015 , they provided services to approximately 50,000 of the approximately 301,000 persons who self-identify as Aboriginal in the province. See Ontario's Aboriginal Health Access Centres, Our Health, Our Seventh Generation, Our Future: 2015 Aboriginal Health Access Centres Report (Toronto: Ontario's Aboriginal Health Access Centres, 2015) at 5-6.

28 The division of powers is complex. Provinces have "direct authority to make and administer laws that deal with financing" while the federal government has authority to indirectly fund programs and attach conditions to its funding. It thus can effectively control provincial policy. See William Lahey, "Medicare and the Law: Contours of an Evolving Relationship" in Jocelyn Downie, Colleen M Flood \& Timothy Caulfield, eds, Canadian Health Law and Policy, 4th ed (Toronto: LexisNexis, 2011) 1 at 29.

29 The Constitution Act, 1867 (UK), 30 \& 31 Vict, c 3, s 91(24), reprinted in RSC 1985, Appendix II, No 5 .

MacIntosh, "Responsibilities and Obligations," supra note 26 at 592-96.

The federal government had historically disavowed jurisdictional responsibility for Inuit persons. This position was found to be in error in Reference as to Whether the Term "Indians" in Head 24 of Section 91 of the British North America Act, 1867, Includes Eskimo Inhabitants of the Province of Quebec, [1939] SCR 104.

32 The various versions of the Indian Act have set out criteria for a person to have their name placed on a registry of "Indians." Such persons have "status" as Indians. The current criteria turns on an individual having at least two grandparents who themselves qualified for status. It is, in effect, a 25 percent blood quantum rule. See Pamela D Palmater, Beyond Blood: Rethinking Indigenous Identity (Saskatoon: Purich Publishing, 2011) at 32. 
persons. ${ }^{33}$ This position has long been critiqued as wrong in law, ${ }^{34}$ and was formally rejected by the Supreme Court of Canada in $2016 .{ }^{35}$ (The potential implications of this decision for the future of the mental health of Indigenous peoples are discussed in the next section.)

Below, I first discuss some initiatives that concern health care benefits and services that the federal government insures for status First Nations persons and Inuit persons. I then turn to community-focused mental health interventions that the federal government funds for First Nation reserve communities and Inuit communities. The offered analysis illustrates that many of the federal government's Indigenous-specific initiatives fail to meet their meritable objectives because they are underfunded or inaccessible. The mental well-being of Indigenous peoples will be improved if the federal government does not just create programs, but also makes them meaningfully operational.

\section{A. The Non-Insured Health Benefits Program: Mental Health Benefits}

One key mental health support that status First Nations and Inuit are supposed to have access to is emergency mental health crisis counselling. While the manner in which this benefit operates has been criticized, there is no suggestion from Indigenous communities that it should be cancelled — rather, communities want to see its accessibility issues addressed and its effectiveness improved. ${ }^{36}$

The federal government funds the counselling through its First Nations and Inuit Health Branches' (FNIHB) Non-Insured Health Benefits Program (NIHB). NIHB includes several benefits to supplement those provided by provinces to all residents as a part of provincial medicare services. NIHB is designed and administered by the federal government, except in British Columbia, where the whole NIHB program was transferred to the then newly created British Columbia First Nations Health Authority in 2013. (Although the British Columbia First Nations Health Authority has the ability to modify the benefits programs, they appear to have left the mental health crisis benefit unchanged. ${ }^{37}$ ) The benefit provides for an initial assessment and 15 one-hour sessions per mental health crisis, all of which must be delivered within a 20 -week period. ${ }^{38}$ 33 For a discussion of how Canada imposed legal categories and groupings on Indigenous peoples and
communities, and how those categories have in turn been used to justify treating segments of the Indigenous population in different ways, see MacIntosh, "Responsibilities and Obligations," supra note 26 at $580-83$.

34 See e.g. Constance MacIntosh, "Jurisdictional Roulette: Constitutional and Structural Barriers to Aboriginal Access to Health" in Colleen M Flood, ed, Just Medicare: What's In, What's Out, How We Decide (Toronto: University of Toronto Press, 2006) 193-215.

35 Daniels v Canada (Indian Affairs and Northern Development), 2016 SCC 12, [2016] 1 SCR 99 [Daniels].

36 AFN-FNIHB NIHB Joint Review Steering Committee, First Nations Mental Wellness and the NonInsured Health Benefits (NIHB) Short Term Crisis Intervention Mental Health Counselling (STCIMHC) Benefit (Ottawa: Assembly of First Nations, November 2015) [2015 AFN-FNHIB review]. Comments from this review are discussed in the body of this article, below.

37 The description of the benefit in their materials is quite general, but does not appear to have introduced any changes. First Nations Health Authority, Health Benefits Information Package (Vancouver: First Nations Health Authority) at 14, online: <www.fnha.ca/Documents/FNHA_HealthBenefits_Info Package.pdf $>$.

38 Health Canada, Guide to Mental Health Counselling Services: Non-Insured Health Benefits (NIHB) Program and the Indian Residential Schools Resolution Health Support Program (IRS RHSP) (Ottawa: Health Canada, 2015) at 3.3, online: $<$ www.hc.sc.gc.ca/fniah-spnia/nibh-ssna/benefit-prestation/crisisurgence/guide-eng.php $>$. Note: An additional five sessions may be approved to enable transition to another service. 
Program eligibility criteria dictate that the coverage is for "crisis situations when no other mental health services are available and/or being provided," to support the provision of "immediate psychological and emotional care" for persons who are "in significant distress" with the purpose of stabilizing their condition, and minimizing the potential for trauma from acute life events. ${ }^{39}$ The health service provider must identify (as part of the mandatory preapproval process) a plan for transitioning the Aboriginal person in crisis to provincial or other mental health supports once the sessions expire.

In 2015, the Assembly of First Nations and Health Canada's First Nations and Inuit Health Branch (Non-Insured Health Benefits Program) performed a substantive review of the program, which included a survey-based evidence gathering process. Its findings point both to the value and deficits of the benefit. As discussed below, this benefit does not necessarily serve its stated purpose of providing "immediate care." More importantly, both users and service providers find it is not responsive to stopping cycles of mental health crises. If it continues to operate as it has, this benefit's potential for making the future of Indigenous mental health look different from the present is limited.

Merely trying to initiate the pre-approval process has proven challenging for persons in need. Consultations with First Nations persons who sought to access the benefit found that phone lines were closed outside of business hours, and that messages requesting referrals for urgent mental health counselling were not consistently returned. ${ }^{40}$ The failure to create a delivery system that responds to urgency, especially when a qualifying criterion for the program is that the individual is in crisis, points to the disjuncture between what the benefit is supposed to do and what it means in practice. In their comprehensive analysis of what is known to work to address Indigenous youth suicide and suicidal ideation, Kirmayer et al. emphasize the value of "immediate intervention" and confirm that "[r]apidly deployed crisis services are probably the best intervention in this regard." ${ }^{41}$ Once the pre-approval process is initiated, the service providers themselves - the mental health counsellors - experience further delays before they can initiate "immediate" care. According to the survey, over onethird found the approval process to be slower and more cumbersome than comparable programs. ${ }^{42}$ These front-end barriers result in undermining access and fail to enable those experiencing a mental health crisis to receive support as intended by this program. Surely the UNDRIP commitment - to take the necessary steps to realize the highest attainable standard of mental health - embraces not just designing programs, but also creating a delivery structure where it is plausible the stated objectives can be met.

Once approved, the benefit often supports the goal of providing a level of essential crisis support. ${ }^{43}$ However, requiring the health care provider to make a plan for continuing care through another program has not reliably resulted in care actually continuing. Continuity of

Ibid at 1.2 .

2015 AFN-FNHIB review, supra note 36 at 19.

Laurence J Kirmayer et al, "Current Approaches to Aboriginal Youth Suicide Prevention" (Montreal: Jewish General Hospital, July 2009) at 97.

2015 AFN-FNHIB review, supra note 36 at 35.

While the review supported continuing the benefit, it also noted several substantive areas for improvement. For example, only half of the Indigenous individuals and communities who responded to their survey felt it was being delivered in a culturally safe manner. This led the reviewers to recommend that NIHB and First Nations work together on providing service providers from "Westerntrained programs" with an understanding of matters such as intergenerational trauma, colonization, and the history of Indigenous health. Ibid at 27. 
care and follow-up have been identified as particularly important for individuals who have had a period of suicidal ideation. ${ }^{44}$ The Joint Review found "significant challenge[s] in ensuring follow-up when a client moves from short-term crisis counselling to longer-term programs." ${ }^{\prime 5}$ Nearly three-quarters of the service providers (72 percent) felt that being required to transfer care, instead of continuing to work with the Indigenous client themselves, did not support a continuum of services. ${ }^{46}$ They referenced the complexities of developing a relationship of trust, and point out how the allocated sessions seldom permitted them to work on the underlying issues that precipitated the crisis, a process that could only take place after trust had been built. Further, over four-fifths ( 82 percent) of the service providers felt that they were unable to accomplish an easy transition to longer-term community treatment programs. ${ }^{47}$ This number roughly aligns with the reported experiences of Indigenous clients, of whom only 15 percent indicated they were able to transition to other supports. ${ }^{48} \mathrm{Cited}$ causes for this problem included no program being available, existing programs being too expensive or too far away for the client to access, and long wait lists. ${ }^{49}$

As a result, the underlying mental health needs that precipitated the recognized crisis are left at risk of continuing unaddressed, and precipitating subsequent crisis moments (which would then, ironically, enable the Indigenous individual to once again access urgent care perhaps with the health care professional who had previously assisted them, but was forced to stop working with them). The AFN-FNIHB review commented that given the histories of trauma that many First Nations persons carry, treatment opportunities had to continue beyond the crisis situation. ${ }^{50}$ It is self-evident that this benefit must be modified to reflect the actual context in which it operates, and be coupled with a realistic plan for continuing care.

One of the more disappointing aspects of this benefit is that it does not seem to contemplate either the practice or the costs of bringing elders or other traditional Indigenous knowledge keepers into the circle of care. Back in 2003, the Advisory Group on Suicide Prevention identified a series of short-term recommendations that should immediately be put into place. One of these recommendations was expanding the NIHB mental health and crisis benefits to explicitly include funding for traditional healers and elders. ${ }^{51}$ Twelve years later, the 2015 AFN-FNHIB review noted that they had repeatedly heard concerns that traditional healing practices were not being adequately supported by the benefit. ${ }^{52}$ While the joint committee acknowledged the inappropriateness of NIHB staff making determinations of community elders and mental wellness practitioners who should be recognized as "equipped to administer traditional/cultural mental wellness counselling," 53 they recommended that NIHB staff and Indigenous communities work together "to identify key cultural leaders and mental wellness practitioners within First Nation communities who are equipped to

Supra note 41 at $98-99$.

2015 AFN-FNHIB review, supra note 36 at 20.

Ibid at 37.

Ibid at 37.

Ibid at 26.

Ibid at 37.

Ibid at 40.

Advisory Group on Suicide Prevention, Acting on What We Know: Preventing Youth Suicide in First Nations (Ottawa: Health Canada, 2003) at 72 [AGSP, Acting on What We Know].

2015 AFN-FNHIB review, supra note 36 at 18.

Ibid. 
administer traditional/cultural mental wellness counselling." ${ }^{, 54}$ Given that Health Canada was a co-author of this report, the implication seems to be that the NIHB benefit was on the cusp of being changed to recognize and provide the resources necessary to fund elders and other Indigenous mental wellness expects. As of 2016, this change has not taken place. The terms of the benefit continue to exclude expenses associated with bringing in traditional healers, as the benefit requires the care be provided by mental health counsellors who are "registered with a legislated professional regulatory body and eligible for independent practice in the province/territory in which the service is being provided." 55 Elders do not belong to a legislated professional regulatory body. Given that implementing UNDRIP requires respecting the right of Indigenous peoples "to their traditional medicines and to maintain their health practices," ${ }^{, 56}$ a future where Canada continues to exclude Indigenous elders and healers from the funding regime will be a future where Canada fails in its commitments.

The practical inaccessibility of the counselling benefit was noted over a decade ago. The Advisory Group on Suicide Prevention-Canada expressed concern about how support for First Nations persons in crisis was structured and channelled; the advisory group was particularly concerned about the frequency with which Indigenous persons in need were being directed to medicated responses. (Another benefit that is provided under the NIHB program is insurance coverage for many commonly prescribed drugs.) They noted that from 1999 to 2000, mental health counselling accounted for \$8.9 million of NIHB expenditures. In the same year, almost $\$ 4.5$ million was spent covering the cost of anti anxiety medications. ${ }^{57}$ In their analysis of this and other data, that Advisory Group on Suicide Prevention linked the high use of such medications to the inadequate availability of mental health counselling, both through the crisis counselling benefit and other sources. ${ }^{58}$ Another recognized response for mental health needs is community heath initiatives.

\section{B. COMmUNITY HEALTH INITIATIVES}

The federal government sponsors several community health programs for First Nations reserve communities and Inuit communities. In the interests of space, I only discuss two here, "Brighter Futures" and "Building Healthy Communities." The programs can either be administered by the federal government or transferred to the community to administer. The latter option is the norm. ${ }^{59}$ These programs raise concerns, but also hold much promise, in part because communities design their own initiatives. Community-designed and operationalized mental health initiatives enable a shift toward collective well-being on a number of levels, including acknowledging that Indigenous individuals and communities are best placed to know their own priorities. ${ }^{60}$ However, there are some perverse elements at the

Ibid.

Supra note 38 at 2.1 .

UNDRIP, supra note 6 , art 24(1).

As cited in AGSP, Acting on What We Know, supra note 51 at 65.

Ibid.

For a discussion of health transfer policies, and the sorts of programming which can be delegated to communities who have not yet entered into a self-government agreement, see MacIntosh, "Responsibilities and Obligations," supra note 26 at 598-605.

60 See e.g. National Collaborating Centre for Aboriginal Health, Setting the Context: The Aboriginal Health Legislation and Policy Framework in Canada (Prince George: National Collaborating Centre for Aboriginal Health, 2011) at 3. 
operational level, resulting in those communities that are doing relatively well having the potential to flourish, while those at risk likely remain at risk.

Brighter Futures was initiated in 1992 and supports five types of community-based initiatives where communities determine their own priorities. One option is to fund "community-based mental health programs, services and/or activities." ${ }^{61}$ Building Healthy Communities was initiated in 1994 to complement the mental health programming through Brighter Futures, support responding to and healing from mental health crisis situations, as well as develop initiatives to address solvent abuse. These programs do not appear to have been formally reviewed since their first evaluation, which was undertaken in 2003. That review identified community-developed mental health crisis management as a key goal of the programs, which should continue to be a goal, but noted it was in practice "hard to address by many communities because of limited resources, capacity, access to training and other factors like community size and isolation." ${ }^{62}$ The review also noted that while training had improved since 1992, "there are ongoing and unmet training and staff development needs." 63 Commenting on programming in 2015, an AFN-Health Canada joint initiative made observations that suggested these deficiencies, identified a decade earlier, continued. In particular, they noted many communities were only able to employ paraprofessional staff who, due to funding constraints and priorities, "might receive only limited mental health training to offer community-based suicide prevention or mental health promotion programming"; furthermore, the joint initiative noted the majority of communities had "no staff dedicated to mental health." 64

Further disjuncture between the ideas behind these programs, and their structure and potential to achieve their goals becomes apparent when one considers the approach to funding. Building Healthy Communities and the Brighter Futures programs result in funding being made available to communities on a per capita basis. This approach treats communities that have multiple risk factors for crisis the same as communities that may be experiencing better mental health. The result is that communities with, for example, low suicide rates can direct their funding toward primary health promotion initiatives, and thus likely improve community mental well-being. Communities that are starting from a point of crisis must direct their funds to tertiary protection, supporting those who have been affected by suicidal behaviour or attempts, and bereaved family and community members. ${ }^{65}$ This undermines the ability of communities to take progressive action. It also raises the question of why the federal government has not adopted a needs-based approach to funding to address the mental health needs targeted by these programs. Like the mental health crisis counselling benefit, these programs are most likely to bring meaningful support and enhanced well-being in a sustainable fashion when crises are an aberration and not the norm. If policies and protocols do not change, the future looks quite different depending upon where a community starts.

Health Canada, "Brighter Futures and Building Healthy Communities," online: $<$ www.hc-sc.gc.ca/fniahspnia/promotion/mental/brighter_grandir-eng.php $>$.

62 Health Canada, Brighter Futures \& Building Healthy Communities Initiatives: Evaluation Summary: September 2006 (Ottawa: Health Canada, 2006) at 4.

Ibid at 5 .

64 Assembly of First Nations \& Health Canada, First Nations Mental Wellness Continuum Framework (Ottawa: Health Canada, January 2015) at 27.

65 See discussion in AGSP, Acting on What We Know, supra note 51 at 70-71. 
In 2003, an advisory group jointly appointed by the Assembly of First Nations and Health Canada's NIHB branch identified changes that would likely address the deficits in community health initiatives. The group advocated for need-based funding for community mental health programs. They recommended creating a community profiling system to proactively identify communities at high risk for mental health crisis, and that high-risk communities be offered "professional mental health services and cultural/traditional health services on a proactive basis before full-blown crises develop."

The advisory group was particularly troubled that supplemental support was often reactive, and, in particular, that a community's ability to garner support seemed to be dependent upon media. ${ }^{67}$ This pattern appears to still be at play. According to the Eskasoni First Nation in Nova Scotia, after an outbreak of suicide attempts in their community in 2009 , federal and provincial funding was provided to support training mental health crisis workers who were fluent in Mi'kmaq, and operate a mental health crisis line. The community credits this initiative with having helped to drastically reduce suicide attempts in their community. ${ }^{68}$ However, the community reports that this initiative lost its funding in 2014 when Nova Scotia adopted a province-wide telephone line. The health director states she was told by Health Canada that any applications for funding their crisis line would not be granted, and summarized their experience as one where, "[o]nce our crisis was out of the headlines, all of the funding dried up." ${ }^{69}$ Similar experiences are documented with regard to other Indigenous communities where, following media attention to a crisis, resources were increased, but then not left in place long enough and eventually withdrawn as public attention shifted. ${ }^{70}$ The issue here is not that resources, once granted, should be assumed to be committed forever. The issue is that there does not appear to be any review mechanism or process in place that is being deployed to assess whether the heightened levels of funding ought to be continued so as to prevent the future from mirroring the past.

For many years, the above programs were effectively supplemented by the work of the Aboriginal Healing Foundation (AHF), which was established in 1998 to fulfill some of the recommendations of the Royal Commission on Aboriginal Peoples. It supported the development and delivery of "community-based Aboriginal directed healing initiatives which address the legacy of physical and sexual abuse suffered in Canada's Indian Residential School System, including inter-generational impacts."

\section{$66 \quad$ Ibid at 75}

$67 \quad$ Ibid at 71 .

68 The Canadian Press, "Eskasoni First Nations Frustrated by Suicide Line Funding Lapse," CBC News (15 April 2016), online: <www.cbc.ca/news/canada/nova-scotia/funding-suicide-prevention-hotlineattawapiskat-1.3537 $318>$.

$69 \quad$ Ibid.

$70 \quad$ See e.g. Ontario, Legislative Assembly, Official Report of Debates (Hansard), 41st Leg, 1st Sess, No 158 (11 April 2016) at 8499 (Gilles Bisson). In Question Period, Mr. Gilles Bisson asked Hon. Kathleen $\mathrm{O}$. Wynne about the infusion of resources that followed the declaration of a state of emergency in the James Bay area, and how those funds were withdrawn a few years later, leaving the communities once again without adequate resourcing. When Bisson first raised this issue, in 2012 when the funding was withdrawn, he noted that "headway" was starting to be made with this funding because programs and staff were in place. See Ontario, Legislative Assembly, Official Reports of Debates (Hansard), 40th Leg, 1st Sess, No 78 (12 September 2012) at 3567-68 (Gilles Bisson); see also Gilles Bisson, Press Release, "Bisson Questions the Removal of Suicide Prevention Funding" (12 September 2012), online: $<$ www.gillesbisson.ca/bisson-questions-the-removal-of-suicide-prevention-funding/>.

71 Aboriginal Healing Foundation, "What is the Aboriginal Healing Foundation?" online: $<$ www.ahf.ca/ faqs $>$. 
extremely successful in terms of enabling meaningful mental health initiatives. ${ }^{72}$ Its funding came to an end in 2014. Similarly, the emergency mental health counselling benefit has been complemented by the Indian Residential School Resolution Health Support Program (IRSRHSP), a counselling benefit that was legislatively mandated as part of the Indian Residential School Settlement. It, too, has been considered very successful, in part because it allowed for family counselling and also because its access criteria presented significantly fewer barriers. The IRSRHSP expired in $2016 .^{73}$ The federal government does not appear to have considered how it will fill the gap that the AHF left behind, nor address the mental health needs that are currently being filled via the IRSHSP.

Programs that are known to work to address the issues the federal government has committed to addressing — and that were developed by or in cooperation with Indigenous peoples from the start - are discontinued. Programs that are identified as needing reform if they are to realize their potential are kept in place, but apparently without the identified operational reforms being undertaken.

In the future, if federally supported programs consistently adopt criteria that enables instead of blocks access, fund to enable functionality, and learn from the operational successes of the AHF and the IRSHSP, the situation could be much brighter. That is to say, if the federal government commits to achieving its stated program goals, it already has blueprints for improving its success.

I turn now to a second example, which permits a focus on the mental well-being of Metis and non-status First Nations persons, and what it should mean if a recent Supreme Court of Canada decision is implemented in good faith.

\section{Implementing the Promise of DANIELS V. CANADA (INDIAN AFFAIRS AND NORTHERN DEVELOPMENT)}

In the coming years, there is significant potential for the mental health of Metis and nonstatus First Nations persons to improve. This prediction is contingent on Daniels v. Canada (Indian Affairs and Northern Development), ${ }^{74}$ which affirms aspects of Manitoba Metis Federation v. Canada (Attorney General), ${ }^{75}$ being respected and acted upon in good faith. Among other matters, in Daniels the Court issued a declaration that Metis and non-status First Nations persons are "Indians" for the purpose of section 91(24) of the Constitution Act. ${ }^{76}$ This undermines the basis on which the federal government claimed it could disavow

See e.g. Marlene Brant Castellano, "A Holistic Approach to Reconciliation: Insights from the Research of the Aboriginal Healing Foundation” in Marlene Brant Castellano, Linda Archibald \& Mike DeGagné, From Truth to Reconciliation: Transforming the Legacy of Residential Schools (Ottawa: AHF, 2008) at 383; Wayne K Spear, Full Circle: The Aboriginal Healing Foundation \& the Unfinished Work of Hope, Healing \& Reconciliation (Ottawa: AHF, 2014). See also Sim Sahar Zerehi, "Plight of Inuit Healing Centre in Ottawa Highlights North's Lack of Mental Health Care," CBC News (15 February 2016), online: <www.cbc.ca/news/canada/north/plight-of-inuit-healing-centre-in-ottawa-highlightsnorth-s-lack-of-mental-health-care-1.3448218 > for a discussion of how closing the AHF has negatively affected Indigenous communities' mental health services.

MacIntosh, "Indigenous Peoples," supra note 8 at 435.

Daniels, supra note 35.

Manitoba Metis Federation Inc v Canada (Attorney General), 2013 SCC 14, [2013] 1 SCR 623 [Manitoba Metis].

Daniels, supra note 35 at para 50. 
responsibility for the well-being of Metis and non-Status First Nations persons. The Court also verified it is "settled law" the federal government has fiduciary obligations to these Indigenous populations. ${ }^{77}$ As noted in the previous section, although the federal government has designed and implemented Indigenous-specific mental health programs and services, it has largely refused to extend these benefits to Metis and non-status First Nations persons, ${ }^{78}$ despite all Indigenous peoples experiencing significant health disparities.

In this section, I first describe the nature of the acute and long-standing mental health risk factors often experienced specifically by non-status First Nation and Metis persons. I then consider how Daniels may have direct and positive impacts on the future availability of mental health programming and policies that support the distinct needs and interests of nonstatus First Nations and Metis persons. Finally, I consider likely future impacts for mental well-being that are of a more indirect character. These impacts have to do with the enabling conditions arising from Daniels that are conducive to a greater sense of positive identity, community belonging, and historic affirmation. These matters are intimately linked with Indigenous mental well-being. ${ }^{79}$

\section{A. Historic BACKDROP}

As has been well-documented and analysed, shortly after Confederation and the enactment of the Constitution Act, 1867 the Dominion government began exercising its jurisdiction under section $91(24) .{ }^{80}$ It created a legal regime concerning the rights of and restrictions imposed upon "Indians and lands reserved to the Indians," which had particularly harsh impacts for First Nations communities. These early laws included definitions of who was an "Indian." All such people would have their name placed on a registry, with the registry serving as conclusive proof of their status as an "Indian." These lists operated as the touchstone for the rights regimes that were created under federal legislation, which in turn meant that those members of the First Nation community who did not meet the criteria for registration were denied political and civil rights within reserve communities, ${ }^{81}$ and were precluded from residing on reserve land. Indigenous women's right to be registered as "Indians" came to be derived from whether they were born of a father with status, and then whether they married a husband with status. ${ }^{82}$ Along with sexism, the regime fostered intra-

Daniels, ibid at para 53.

Estimates are that about one-third of Indigenous people have no access to any federal programs or services that are tailored to specifically support the needs of Indigenous people. Canada, Standing Senate Committee on Social Affairs, Science and Technology, Out of the Shadows at Last: Transforming Mental Health, Mental Illness and Addiction Services in Canada (May 2006) at 287 [Out of the Shadows].

79 See e.g. Miranda Dyck, Social Determinants of Métis Health (Ottawa: National Aboriginal Health Organization, 2009).

80 See MacIntosh, "Responsibilities and Obligations," supra note 26 at 584-88.

81 Even those who did meet the criteria to be registered lost rights if they resided off of reserves. This issue, and in particular a requirement of the Indian Act that only those who lived on a reserve could vote in a band council election, was the subject of Corbiere v Canada (Minister of Indian and Northern Affairs), [1999] 2 SCR 203. Importantly, the Court found that the creation of different rights, depending on residency, perpetuated the idea that those band members who lived off reserves were less vested in their cultural identify and home Indigenous community, and that this discrimination violated their section 15 Charter rights of equality.

82 Even if women met the criteria for status, their rights remained second class, as they were denied both property ownership rights and civic rights such as voting. This regime resulted not just in sexist policies, but also entrenched and thus normalized sexism within Indigenous communities. It is associated with gendered violence and sexual abuse of Indigenous women and girls. See Billie Allan \& Janet Smylie, 
group racism, ${ }^{83}$ and lateral violence. ${ }^{84}$ All of these issues intersect with and are entailed in Indigenous mental health. ${ }^{85}$

This regime also forced physical separations within families, as women who married men without status were no longer legally "Indians." As a result, they had to leave their home communities and raise their children as outsiders. The elements of identity that rest on community inclusion, having a home, and ancestors to return to, were taken from them, and cultural discontinuity, a major risk factor for poor mental health for Indigenous peoples, was fostered.

In 1985, laws changed; the most blatantly sexist provisions were removed, and First Nation bands were recognized as having the right to determine band membership, which includes rights of residency on reserve land. However, the federal government still controlled the definition of "Indian" under the Indian Act, and thus who qualified for status. While this meant that First Nations could now welcome back their relations who did not have "Indian" status, such a decision was not structured to be cost-neutral for the community. Many of the federal programs that reserve communities depend upon, including their mental health and community services programs, are funded according to the number of First Nations persons with registered status in a community, not the actual size of the First Nation community. This placed many First Nations communities in an unconscionable position. If they opened the doors to non-status First Nations relations to return as members, it could make their already underfunded health programming — and other programming — even more inadequate. This is an ugly structure. It pushes communities to embrace deeply problematic conceptualizations of rights of inclusion. It produces financial incentives within Indigenous communities to selfadminister distinctions that disable collective relations and deny memory of shared identities, ${ }^{86}$ and to do so as a strategy for survival. This is also a mentally unhealthy structure, perpetuating social exclusion and associated psychological harm.

Metis people have also experienced distinct social and psychological harm from Canada's position on their legal status and identity. In particular, colonial laws, policies, and beliefs supported the oppression and the legal erasure of Metis persons as Indigenous peoples. Although Metis fought to have their political, legal, and land rights respected, the Northwest Resistance was unsuccessful and culminated in 1885 with the execution of the Metis leader, Louis Riel, for the crime of treason. ${ }^{87}$ While largely denying them any benefits that the federal government directed to status First Nations persons, and failing to diligently fulfill constitutional obligations owed directly to them with deleterious effects, ${ }^{88}$ the state

First Peoples, Second Class Treatment: The Role of Racism in the Health and Well-Being of Indigenous Peoples in Canada (Toronto: Wellesley Institute, 2015) at 3.

Palmater, supra note 32 at 57.

Allan \& Smylie, supra note 82 at 19.

There is strong writing concerning how Indigenous women experience the adverse effects of the intersectionality of racism and sexism, and how colonialization has supported in-group oppression of Indigenous women. See e.g. Rauna Kuokkanen (2015) "Gendered Violence and Politics in Indigenous Communities" 17:2 Intl Feminist J Politics 271.

MacIntosh, "Relational Theory," supra note 15 at 231.

Mental Health Commission of Canada, supra note 13 at 102.

Manitoba Metis, supra note 75. 
nonetheless imposed many direct hardships. ${ }^{89}$ Writing about Metis people, Allan and Smylie observed:

While on the one hand they have faced legislative efforts to obscure their Indigeneity, the Métis have been continuously subjected to the assimilationist and exclusionary policies and practices of the Canadian government towards Aboriginal peoples, including land dispossession, political persecution, economic exclusion, residential schooling, the Sixties Scoop and ongoing invasive child welfare intervention. ${ }^{90}$

Metis identity has operated as a target and as a touchstone for identifying who requires assimilation and erasure, thus creating a "powerful disincentive" for Metis people to acknowledge and thrive in their cultural, political, and legal identity. ${ }^{91}$ It is not surprising that colonialism and racism emerge as key social determinants of health for Metis people, and that as a result they experience gross health disparities. ${ }^{92}$

\section{B. LIKELY DIRECT IMPACTS OF DANIELS FOR MENTAL SUPPORTS AND RESOURCES}

With the key exceptions of Alberta and the Northwest Territories, which have recognized Metis people as distinct Indigenous peoples with certain rights, ${ }^{93}$ provincial governments have often resisted assuming responsibility to fill the health care gap with Indigenousspecific programming. This resistance has been rationalized on the basis that jurisdictional responsibility lay with the federal government, ${ }^{94}$ and so, at best, support is limited to provincial legislation that permits the creation of tripartite agreements for a province to deliver health care services to First Nations. ${ }^{95}$ As a result, Metis and non-status First Nations populations have generally had to turn to provincial programs designed to serve the general Canadian population. In effect, they have been forced to seek mental health care through programs that were designed as though colonialism never happened, even though colonialism is a social determinant of health for all Indigenous peoples. ${ }^{96}$ It is little surprise, then, that provincially designed and delivered programs are often described as needing considerable changes if they are to provide not just a culturally competent space where health care providers are sensitized to cultural and worldview differences, but also a culturally safe source of care..$^{97}$ (Culturally safe health care turns on the delivery recognizing the "cultural,

Daniels, supra note 35 at para 32.

Allan \& Smylie, supra note 82 at 12 [citation omitted].

Mental Health Commission of Canada, supra note 13 at 102.

Allan \& Smylie, supra note 82 at 12. See also Dyck, supra note 79 at 13.

Alberta has sought to fill obligations to Metis people through the Metis Settlements Act, RSA 2000, c M-14, Schedule 1, ss 4, 12. The Act recognizes Metis settlements as having limited authority over some health matters. In the Northwest Territories, and as contemplated by the Sahtu Dene and Metis Comprehensive Land Claim Agreement, Canada and Sahtu Tribal Council, 6 September 1993, QS-5315000-EE-A1 (entered into force 6 September 1993), the Northwest Territories administers a program that imports several, but not all elements of the NIHB program into its regime for Metis peoples. See "Metis Health Benefits" Northwest Territories Health and Social Services, online: <www.hss.gov.nt.ca/ health/nwt-health-care-plan/metis-health-benefits>.

Out of the Shadows, supra note 78 at 378.

See e.g. Public Health Act, SNB 1998, c P-22.4, s 58(1).

MacIntosh, "Responsibilities and Obligations," supra note 26 at 577.

Annette J Browne et al, "Access to Primary Care From the Perspective of Aboriginal Patients at an Urban Emergency Department” (2011) 21:3 Qualitative Health Research 333 at 334. A recent Torontobased study determined that Indigenous people may fail to be taken seriously by health care providers when they seek care within provincially delivered systems, and linked that failure to racism which was operating both on individual and systematic levels: Allan \& Smylie, supra note 82 at 27. The study presented chilling examples of Indigenous individuals strategizing about how to get access to care and 
historical, and structural differences and power relationships within the care that is provided." ${ }^{98}$ ) The failure to provide mental health programming and supports that are designed and delivered in a manner that directly responds to colonialism and its continuing consequences is by definition a failure to provide culturally safe care.

The declaration of jurisdictional responsibility in Daniels does not, per se, require the federal government to step forward and provide resources to enable the creation and delivery of Indigenous specific and culturally safe mental health care for Metis and non-status First Nations persons. ${ }^{99}$ It is, however, a complete answer to the reason the federal government has always offered to justify its failure to act - which was that they lacked jurisdiction to do so. ${ }^{100}$ That answer can no longer be relied upon to excuse inaction. Nor can Canada continue to justify limiting the scope of its responsibilities by using the definitions for registration under the Indian Act as the definitive gateway for accessing Indigenous-specific health care. I note that declarations and findings of fact have also had significant political force in Canada vis-à-vis the federal government and Indigenous peoples. ${ }^{101}$ The modern treaty process, for example, was initiated in response to a declaration in Calder v. British Columbia ${ }^{102}$ that Aboriginal title interests may have survived confederation. In Delgamuukw v. British Columbia,${ }^{103}$ the requested declaration was not granted due to deficiencies in the pleadings, but the factual findings were sufficiently compelling that the British Columbia government abandoned its position of denying that Indigenous land interests could have continued to the present day, and so joined the treaty process.

Like the decision in Calder, the Federal Court's decision in Daniels v. Canada (Indian Affairs and Northern Development) did not impose any direct obligations, but it did make significant findings of fact. ${ }^{104}$ Read in its entirety, it is clear that the Court identifies the failure of the federal government to act on its historic responsibilities to Metis and non-status First Nations persons as the source of many of the social, economic, political, and health woes of these peoples. Indeed, the pleadings in Daniels FC were grounded in how the federal government's refusal to recognize Metis and non-status Indians as Indians pursuant to section 91(24) resulted in their having "suffered deprivations and discrimination," including "lack of access to health care." "105 Justice Phelan agreed with these characterizations. He found that jurisdictional wrangling had resulted in Metis and non-status First Nations persons being "deprived of programs, services and intangible benefits recognized by all governments as needed." 106

be listened to in a context where they expected — based on past experiences - to be judged by stereotypes and assumed to be drunk or abusing drugs or otherwise blamed for their health condition if their Indigeneity was revealed (ibid at 27).

$98 \quad$ Honouring Our Strengths, supra note 10 at 8.

$99 \quad$ Daniels, supra note 35 at para 15 . See also the discussion in Larry Chartrand, "The Failure of the Daniels Case: Blindly Entrenching a Colonial Legacy" (2013) 51:1 Alta L Rev 181 at 181; Catherine Bell, " $R$. v. Daniels: Jurisdiction and Government Obligations to Non-Status Indians and Metis" in Martin Papillon \& André Juneau, eds, Canada: The State of the Federation 2013, Aboriginal Multilevel Governance (Kingston: McGill-Queen's University Press, 2016) 215 at 223-28.

Daniels, ibid at para 13.

Bell, supra note 99 at 215 .

[1973] SCR 313.

[1997] 3 SCR 1010.

2013 FC 6, [2013] 2 FCR 268 [Daniels FC]

Ibid at para 4 .

Ibid at para 108 . 
The Supreme Court of Canada continued in this vein. They adopted Justice Phelan's characterization, ${ }^{107}$ writing that because no government was willing to acknowledge jurisdiction, Metis and non-status First Nations persons had "no one to hold accountable for an inadequate status quo"108 and were thus left "in a jurisdictional wasteland with significant and obvious disadvantaging consequences." 109 In so far as the requested remedies allowed it to do so, the Court pointed a finger, and certainly contemplated its declaration having consequences. The Court wrote that "assigning constitutional authority between the federal and provincial governments will have enormous practical utility for these two groups who have, until now, found themselves having to rely more on noblesse oblige than on what is obliged by the Constitution."110 A declaration, the Court determined, would ensure "accountability."111 These words, woven together with the finding that a fiduciary relationship exists between all Indigenous peoples and the Crown, ${ }^{112}$ and the constitutionally entrenched obligation on the part of Parliament to seek "reconciliation with all of Canada's Aboriginal peoples"113 suggest that while a declaration cannot in and of itself require positive action, the declaration in conjunction with the constitutionally entrenched obligation to take steps to enable reconciliation, and the presence of fiduciary obligations, ${ }^{114}$ does. Also thrown into the mix is the federal government's commitment to implement the UNDRIP ${ }^{115}$ which, as noted above, recognizes a right for Indigenous people to enjoy "the highest attainable standard" of mental health, and to "take the necessary steps" to progressively realize this right. ${ }^{116}$ Given all this, continuing inaction on supporting the development and delivery of health care, including mental health supports that specifically serve Metis and non-status First Nations, would seem to be neither a legally nor politically viable option for the federal government.

I would not suggest that this obligation be approached by instantly expanding existing mental health programs that were designed specifically for First Nation reserve communities to include all Metis and non-status First Nations persons. Non-status First Nations and Metis persons and communities would not have been considered, consulted, or meaningfully engaged when such programs were designed. ${ }^{117}$ However, some of the programs respond to mental health needs that appear to be present across Indigenous communities. The Mental Health Commission of Canada's 2012 mental health strategy observes that all Indigenous peoples in Canada have mental health needs associated with the intergenerational impacts of colonialism, and that these impacts are a priority issue. In particular, they flag the manifestation of high rates of suicide and the need for a "full continuum of culturally safe

Ibid at paras 107-108; Daniels, supra note 35 at para 14.

Daniels, ibid at para 15.

Ibid at para 14.

Ibid at para 12 .

Ibid at para 15 .

Ibid at para 53.

Ibid at para 37.

I have argued elsewhere, in the context of deficient water quality in reserve communities, that the fiduciary relationship requires the federal Crown to act when its actions were the source of a specific harm. See Constance MacIntosh, "Indigenous Public Health and Fiduciary Liability: Exploring Litigation as an Answer to Unacceptable On-Reserve Water Quality" in Martha Jackman and Bruce Porter, eds, Advancing Social Rights in Canada (Toronto: Irwin Law, 2014).

UNDRIP, supra note 6.

Ibid, art 24(2).

This is not to suggest that First Nations and Inuit persons and communities have been properly consulted or engaged in the development of any particular existing program. 
mental health services, treatments and supports" as common priorities. ${ }^{118}$ Obviously the mental health counselling benefit, described above (and assuming it is improved upon), would be one such reasonably transferrable program. ${ }^{119}$

As well, only First Nation and Inuit communities can apply to receive project-specific federal funding for Indigenous solvent abuse and addictions programming, and Indigenous youth suicide prevention programming. The National Aboriginal Youth Suicide Prevention Strategy (NAYSPS) is a flagstone initiative, and one of the responses to the 2003 report of the Advisory Group on Suicide Prevention. ${ }^{120}$ In its documents describing the intention behind NAYSPS, Health Canada observes:

It will take many years to effectively address the rates of Aboriginal youth suicide. This is because Aboriginal youth suicide is a complex and multi-faceted issue. The experience of many youth is steeped in cultural disintegration, the breakdown of family structures, dislocation from the land, and economic and educational disadvantages due to the intergenerational impacts of colonialism, Indian Residential Schools, and assimilative policies. $^{121}$

Although the above text was drafted to describe the experiences of status First Nation and Inuit youth, there is nothing there that is not also part of the experience of many non-status First Nation and Metis youth.

The NAYSPS funds community proposals that align with addressing specific factors associated with Indigenous suicide risks, including preserving and promoting cultural continuity, pride, and identity. The program thus funds initiatives that are, for example, "[a]ctivities for youth that increase their connection to community, the land, each other, Elders, their family, and that promote cultural continuity." 122 As noted above, due to the impacts of colonialism, these are areas of key concern for the mental well-being of Metis and non-status First Nations persons. Given that proposals are designed by those who seek support, not by the federal government, there is no need, for example, to wait for federal consultations. Rather, communities themselves can directly identify what their community mental health needs are, and how they imagine fulfilling them. I note that for many nonstatus First Nations persons, and indeed many Indigenous persons who live in urban settings, communities are formed in different ways. There are existing community-based organizations that currently host programming for local Indigenous residents. ${ }^{123}$ Going

118 Mental Health Commission of Canada, supra note 13 at 97.

119 While the Northwest Territories extends health care benefits to Metis people largely modelled on Health Canada's NIHB program, their program does not include emergency mental health crisis counselling. See "Metis Health Benefits," supra note 93.

120 Health Canada, National Aboriginal Youth Suicide Prevention Strategy (NAYSPS): Program Framework (Ottawa: Minister of Health, 2013) at 4.

Ibid at 6 .

Ibid at 10 .

The Victoria Native Friendship Centre in B.C. is one example of a community-based centre that offers support and resources to First Nations individuals, including a mental health liaison. The Mi'kmaw Native Friendship Centre in Halifax offers an Aboriginal mental health awareness project. The Ontario Federation of Indigenous Friendship Centres lists six friendship centres as offering mental health services. The Mental Health Commission of Canada offers Mental Health First Aid courses and is developing a version tailed to Canadian First Nations. See "Mental Health First Aid Course Empowers First Nations' Community," Canadian Institutes of Health Research (15 June 2015), online: <www.cihrirsc.gc.ca/e/49062.html>. 
forward, these entities could be a natural venue for channelling the federal community mental health programming that ought to flow as a consequence of the Daniels declaration.

I could elaborate further, but the point is that if the Daniels decision is respected, it is not unreasonable to expect that in the future, an Indigenous youth's ability to access programs such as Indigenous-specific suicide prevention or emergency mental health counselling, or alternatively, to participate in designing and receiving funding for implementing a community mental wellness initiative will not depend upon whether they are registered under the Indian Act. Instead, access will turn on whether they actually need the service or program, or whether the proposed initiative is a sound one. The other direct consequence of Daniels is that Metis and non-status First Nations persons are now unquestionably enabled to enter into a direct conversation with the federal government about their needs and what supports or assistance they would like the federal government to provide as they seek to improve their mental well-being.

\section{INDIRECT CONSEQUENCES: DANIELS IN THE Social SPHERE OF MENTAL WellnesS}

Although conceptual concerns have been raised about the Daniels decision, ${ }^{124}$ I believe it will have positive indirect impacts for the mental well-being of Metis and non-status First Nations persons. I say this for two interrelated reasons. First, the decision clearly extends the declaration of jurisdictional responsibility in relation to Canada's obligation to pursue reconciliation and redress with all Aboriginal peoples to all who self-identify as Indigenous. Second, the decision opens the door for countering some aspects of the deep social and psychological harms, or "cultural traumas," that were caused and perpetuated by how the federal government's position on jurisdiction played out in both the communities and daily lives of Indigenous individuals, which had particularly harsh impacts on Metis and non-status First Nations persons and communities. ${ }^{125}$ That is, the dismantling of aspects of the existing system, which this decision requires, will have effects that transcend the relationship between the federal government and Indigenous peoples to support healthier relationships between Indigenous peoples themselves.

A significant part of this story rests on the creation of registered status under the Indian Act, and how the designation of having "status" or being "registered" has been deployed to divide Indigenous peoples. As noted above, identity and cultural continuity are key social determinants of mental health for all Indigenous peoples. As Pamela Palmater eloquently argues, the concept of status has served to create the idea that the only "real" Indigenous people are those with status, and that those who do not have status are somehow less authentic, less connected, or less committed to their Indigenous identity, and are therefore

See e.g. the discussion of the Constitution Act, 1867, supra note 29, s 91(24) analysis in the trial decision, which was largely adopted by the Supreme Court of Canada, in Chartrand, supra note 99. The Court drew upon a race-based analysis, and was jarring in its reliance upon the Canadian state's historic assimilation goals to interpret section 91(24)'s current meaning. Chartrand particularly critiqued the trial decision because the requested declaration resulted in the plaintiffs being captured as within state sovereignty, as a subject of the state — and thus within what we know to have been an inherently oppressive and colonial regime. 
viewed as imposters. ${ }^{126}$ The harms of the Indian Act regime and the status system to the psychological well-being of First Nations persons and communities is reasonably wellknown, perhaps because it has continued to splinter communities for over a hundred years, but it has also harmed Metis. Metis were historically often required to choose between being recognized as an "Indian" and join a reserve-based First Nation, or be deemed to have left their "Indianness" behind. ${ }^{127}$

The Court's affirmation in Daniels that Canada's obligation to negotiate reconciliation embraces all Indigenous people in Canada means that Canada must take steps to rectify harms and renegotiate the relationship. This forces a radical affirmation of Metis political, social, and legal identity. It builds upon the psychological and social (as well as material) benefits to Metis people arising from the Manitoba Metis Federation declaration, in which there was judicial recognition that the Crown had failed to act honourably toward them and that such treatment was required.

At its heart, the Daniels decision recognizes federal responsibilities to all Aboriginal people, ${ }^{128}$ and the particular harms that Metis and non-status First Nations persons have experienced due to federal posturing and the enactment of regimes that harmed them as Indigenous peoples. In defining the scope of federal obligations, the Court steps back from any requirement of formal community recognition or acceptance for an Indigenous person's self-identification to be recognized as legitimate and attract government obligations ${ }^{129}$ in recognition of the fact that community alienation can often be assumed to have been a product of the colonial regime. This sets the stage for considerable individual and community healing.

The structure of Indigenous health policy in Canada has historically been built upon a framework that denies Indigenous peoples equitable access to mental health and other supports, while also denying them a meaningful right to define who is, and who is not, a member of their community. This has fostered inherently harmful psychological divisions that reject communal history and experiences, and question authenticity. ${ }^{130}$ This has been the world of many non-status First Nations and Metis persons. Given that strong connections to Indigenous identity and culture are identified as key factors for promoting the mental health and well-being of all Indigenous people, ${ }^{131}$ the dismantling of the logic that substantiated operational aspects of the federal system, with its positioning of non-status First Nations persons and Metis persons as not Aboriginal enough, can only have positive consequences for the mental well-being of these populations.

\section{Concluding Comments}

The discussion in the body of the article is very much concerned with the short term. I look at existing programs, and describe what we already know about how they could be

126 This position animates much of Palmater's book. For a specific discussion, see Palmater, ibid at 120.

127 See Constance MacIntosh, "From Judging Culture to Taxing 'Indians': Tracing the Legal Discourse of the "Indian Mode of Life"” (2009) 47 Osgoode Hall LJ 399.

128 Daniels, supra note 35 at paras $19,49$.

$129 \quad$ Ibid at paras $17-18$.

130 MacIntosh, "Relational Theory," supra note 15 at 241.

131 Allan \& Smylie, supra note 82 at 23. 
improved so that their objectives become more attainable. I offer suggestions for how aspects of the Daniels decision could be immediately acted upon, and propose some positive consequences that are likely to arise by virtue of community affirmation and the discrediting of the federal position on jurisdiction (and the regime built upon that position). The future with which I am concerned is the immediate one, imagining what it would take and what it would mean if existing state obligations and commitments were taken seriously.

I think it is particularly significant, for all Indigenous people, that in so far as the statusbased funding structure for First Nations mental health and community care in reserve community settings was ever legitimate, the new interpretation of section 91(24) removes the key ground it stood upon. Communities can no longer be forced to approach their collective identity based on fiscal incentives associated with health care funding formulas. This is liberating and inherently positive for collective well-being.

The broader overhaul of governance that is required for Indigenous peoples to be best positioned to experience well-being is obviously more complicated, and turns strongly on self-determination and the creation of proper fiscal supports. This overhaul will take time to negotiate and put into place. That said, there are positive signs that ground is being won, not lost. Nationally, there are other small but compelling changes in the air. For example, Canada has explicitly committed to fulfilling the Calls to Action of the Truth and Reconciliation Commission, ${ }^{132}$ one of which requires the state government to close gaps in health, and to establish goals for closing those gaps based on health indicators, which include suicide and mental health. ${ }^{133}$ Internationally, Canada recently removed all reservations from its endorsement of the United Nations Declaration on the Rights of Indigenous Peoples, and committed to implementing its terms. ${ }^{134}$ Canadian Indigenous peoples have long been ready for the promised changes. Perhaps these current commitments signal that Canada will follow through.

See e.g. Justin Trudeau, Prime Minister of Canada, "Statement by Prime Minister on Release of the Final Report of the Truth and Reconciliation Commission" (15 December 2015), online: <pm.gc.ca/eng/news/ 2015/12/15/statement-prime-minister-release-final-report-truth-and-reconciliation-commission $>$; Elizabeth McSheffrey, "Trudeau Promises Full Federal Action on Final TRC Report" National Observer (15 December 2015), online: <www.nationalobserver.com/2015/12/15/news/trudeau-promises-immed iate-action-final-trc-report>. session of the United Nations Permanent Forum on Indigenous Issues, New York City, 10 May 2016), as cited in Northern Public Affairs, "Fully Adopting UNDRIP: Minister Bennett's Speech at the United Nations"(11 May 2016), online:<www.northernpublicaffairs.ca/index/fully-adopting-undrip-ministerbennetts-speech/>. 